\title{
TINJ AUAN YURIDIS TERHADAP PERLINDUNGAN HUKUM KORBAN TINDAK PIDANA PENUSUKAN DALAM PERADILAN PIDANA
}

\author{
Nur Rima Cessio Magistri ${ }^{2}$, Nyoman Serikat Putra J aya² \\ 1Fakultas Hukum, Universitas J enderal Soedirman \\ 2Fakultas Hukum, Universitas Diponegoro \\ cessiorima@gmail.com
}

\begin{abstract}
The Indonesian Criminal Code and Laws so far have not specifically and clearly regulated the sanctions or fines applied to the perpetrators of stabbing crimes. This is what requires the renewal of criminal law in terms of specific arrangements regarding the stabbing criminal act. This article aims to find out, study and explain how the Legal Protection of Criminal Victims, especially the Penalties Crime in Criminal J ustice. The results of the study stated that the stabbing could be categorized as premeditated murder as stipulated in Article 340 of the Criminal Code which stated that it was threatened because of a murder with a plan (moord), as well as regulated in Article 6 of Law Number 5 of 2018 concerning Eradication of Terrorism Criminal Acts which stated the Threat of Violence which caused a Violence fear or terror.
\end{abstract}

\section{Keywords: Legal Protection; Stabbing Crimes; Criminal J ustice.}

\begin{abstract}
ABSTRAK
KUHPidana dan Undang-undang hingga saat ini belum ada yang mengatur secara khusus dan jelas mengenai sanksi atau pun denda yang diterapkan kepada pelaku tindak pidana penusukan.Hal ini lah yang memerlukan pembaharuan hukum pidana dalam hal pengaturan secara khusus mengenai tindak pidana penusukan.Artikel ini bertujuan untuk mengetahui, mengkaji dan menjelaskan bagaimanakah Perlindungan Hukum Korban Tindak Pidana khususnya Tindak Pidana Penusukan dalam Peradilan Pidana. Hasil penilitiian menyatakan bahwa Penusukan dapat dikategorikan dalam pembunuhan berencana sebagaimana diatur dalam Pasal 340 KUHPidana yang menyatakan diancam karena pembunuhan dengan rencana (moord), serta diatur dalam Pasal 6 Undang-Undang Nomor 5 tahun 2018 tentang Pemberantasan Tindak Pidana Terorisme yang menyatakan Ancaman Kekerasan yang menimbulkan rasa takut atau teror..
\end{abstract}

Kata Kunci: Perlindungan Hukum; Tindak Pidana Penusukan; Peradilan Pidana

\footnotetext{
${ }^{*}$ Corresponding Author
} 
Jurnal Pembangunan Hukum Indonesia

Volume 2, Nomor 1, Tahun 2020
Program Studi Magister Ilmu Hukum Fakultas Hukum Universitas Diponegoro

\section{A. PENDAHULUAN}

Indonesia merupakan negara hukum. Sebagaimana tercantum dalam Pasal 1 Ayat (3) Undang-Undang Dasar Negara Republik Indonesia Tahun 1945 (yang selanjutnya disebut UUD 1945) (Maksum, 2015). UUD 1945 merupakan hierarki tertinggi dalam Peraturan Perundang-undangan di Indonesia. Karena Indonesia adalah sebuah negara hukum maka setiap perbuatan masyarakat di negara Indonesia harus berdasarkan pada Peraturan Perundang-undangan di Indonesia.

Masyarakat harus mendapatkan perlindungan hukum, karena masyarakat merupakan manusia yang merupakan mahluk sosial yang mempunyai hubungan antara satu dengan yang lain (Wahidin, 2000). Dalam menjalani kehidupan, manusia tidak bisa terlepas dari hukum, karena dari awal lahir hingga pada saat kematian pun selalu membutuhkan hukum. Manusia saling berhubungan antara satu dengan yang yang lain, sehingga seringkali menimbulkan konflik antara satu dengan yang lainnya sehingga harus ada perlindungan (Hidayat, 2016). Perlindungan berfungsi untuk mengayomi seseorang terhadap orang yang lebih lemah. Perlindungan hukum dapat diartikan segala upaya pemerintah untuk menjamin adanya kepastian hukum untuk memberi perlindungan kepada warganya agar hak-haknya sebagai seorang warga negara tidak dilanggar, dan dikenakan sanksi bagi seseorang yang melanggar peraturan tersebut sesuai dengan peraturan yang berlaku, dan akan mendapatkan konsekuensi terutama pada hukum pidana.
Hukum Pidana yaitu suatu ketentuan hukum/undang-undang yang menentukan perbuatan yang dilarang untuk dilakukan dengan ancaman sanksi terhadap pelanggaran larangan tersebut. Banyak ahli berpendapat bahwa Hukum Pidana menempati tempat tersendiri dalam sistemik hukum, hal ini disebabkan karena hukum pidana tidak menempatkan norma tersendiri, akan tetapi memperkuat norma-norma di bidang hukum lain dengan menetapkan ancaman sanksi atas pelanggaran norma-norma di bidang hukum lain. Asas hukum pidana sebagaimana diatur dalam Pasal 1 ayat 1 Kitab Undang-undang Hukum Pidana (KUHPidana) yang menyatakan bahwa hukum pidana bersumber pada peraturan tertulis (undangundang) disebut juga sebagai asas legalitas. Asas legalitas bertujuan untuk memberikan sifat perlindungan pada undang-undang pidana yang melindungi rakyat terhadap pelaksanaan kekuasaan yang tanpa batas dari pemerintah. Tujuan hukum pidana adalah untuk melindungi kepentingan orang perseorangan atau hak asasi manusia dan masyarakat. Tujuan hukum pidana di Indonesia harus sesuai dengan falsafah Pancasila yang mampu membawa kepentingan yang adil bagi seluruh warga negara. Hukum pidana di Indonesia bertujuan untuk mengayomi seluruh rakyat Indonesia.

Tindak Pidana diatur dalam Kitab Undangundang Hukum Pidana (yang selanjutnya disebut KUHPidana) disebut dengan istilah Strafbaarfeit atau biasa disebut delik. Istilah Strafbaarfeit adalah peristiwa yang dapat dipidana atau perbuatan yang 
Jurnal Pembangunan Hukum Indonesia

Volume 2, Nomor 1, Tahun 2020
Program Studi Magister Ilmu Hukum Fakultas Hukum Universitas Diponegoro dapat dipidana. Sedangkan delik dalam bahasa asing disebut delict artinya yaitu suatu perbuatan yang pelakunya dapat dikenakan hukuman.

Penusukan termasuk kedalam salah satu tindak pidana karena merupakan perilaku seseorang yang melanggar hukum yang berlaku dalam suatu negara. Penusukan merupakan suatu tindakan untuk menghilangkan nyawa seseorang dengan cara melanggar hukum, maupun yang tidak melawan hukum. Dalam peraturan perundang-undangan belum ada peraturan khusus yang mengatur mengenai penusukan. Penusukan dapat dikategorikan kedalam pembunuhan berencana sebagaimana diatur dalam Pasal 340 KUHPidana yang menyatakan bahwa "Barang siapa sengaja dan dengan rencana lebih dahulu merampas nyawa orang lain, diancam karena pembunuhan dengan rencana (moord), dengan pidana mati atau pidana penjara seumur hidup atau selama waktu tertentu, paling lama dua puluh tahun. Selain diatur didalam KUHPidana penusukan juga diatur dalam Pasal 6 Undang-Undang Nomor 5 tahun 2018 tentang Pemberantasan Tindak Pidana Terorisme yang menyatakan bahwa "Setiap Orang yang dengan sengaja menggunakan Kekerasan atau Ancaman Kekerasan yang menimbulkan suasana teror atau rasa takut terhadap orang secara meluas, menimbulkan korban yang bersifat massal dengan cara merampas kemerdekaan atau hilangnya nyawa dan harta benda orang lain, atau mengakibatkan kerusakan atau kehancuran terhadap Objek Vital yang Strategis, lingkungan hidup atau Fasilitas Publik atau fasilitas internasional dipidana dengan pidana penjara paling singkat 5 (lima) tahun dan paling lama 20 (dua puluh) tahun, pidana penjara seumur hidup, atau pidana mati" (Folman, 2018).

Menurut Satjipto Rahardjo, penegakan hukum merupakan suatu usaha untuk mewujudkan ide-ide dan konsep-konsep menjadi kenyataan. Secara konsepsional, pengertian penegakan hukum terletak pada kegiatan hubungan nilai-nilai yang ada di dalam kaidah-kaidah dan sikap akhir untuk menciptakan, memelihara dan mempertahankan kedamaian. Penegakan hukum pidana adalah suatu usaha untuk mewujudkan ide-ide tentang kedilan dalam hukum pidana dalam kepastian hukum dan kemanfaatan sosial menjadi kenyataan hukum dalam kepastian hukum dan kemanfaatan sosial menjadi kenyataan hukum dalam setiap hubungan hukum (Ediwarman, 2012)

KUHPidana dan Undang-undang hingga saat ini belum ada yang mengatur secara khusus dan jelas mengenai sanksi atau pun denda yang diterapkan kepada pelaku tindak pidana penusukan. Hal ini lah yang memerlukan pembaharuan hukum pidana dalam hal pengaturan secara khusus mengenai tindak pidana penusukan. Rumusan masalah yang dikaji dalam penelitian ini adalah mengenai bagaimana unsur-unsur tindak pidana penusukan dalam peradilan pidana dan bagaimana perlindungan hukum korban tindak pidana penusukan dalam peradilan pidana.

Terkait dengan penelitian ini, sebelumnya telah ada yang melakukan penelitian yang pada 
Jurnal Pembangunan Hukum Indonesia

Volume 2, Nomor 1, Tahun 2020
Program Studi Magister IImu Hukum Fakultas Hukum Universitas Diponegoro pokoknya berfokus pada tindak pidana penipuan bisnis online (Amalia, Siswanto, \& WN, 2017). Penelitian yang kedua berfokus pada tindak pidana kekerasan terhdap anak yang dilakukan oleh anak (Wijaya, 2017). Penelitian yang ketiga berfokus pada penegakan hukum terhadap tindak pidana yang terkait dengan ujaran kebencian (Chandra, 2017). Penelitian selanjutnya yang dibuat dalam bentuk jurnal internasional yaitu Correlation between theory of criminal liability and criminal punishment toward corporation in indonesia criminal justice", didalamnya membahas tentang korelasi tentang pertanggungjawaban pidana terhadap tindak pidana korporasi (Sudira, 2014). Penelitian berikutnya berfokus pada Tindak Pidana Penipuan Berbasis Transaksi Elektronik (Rohmanto, 2019).

Berdasarkan penelitian sebelumnya terdapat perbedaan yang menunjukan kebaruan dalam penelitian ini yaitu penulis membahas mengenai tindak pidana penusukan yang belum diatur secara khusus dalam peraturan perundang-undangan. Tujuan dari penulisan ini yaitu untuk mengetahui, mengkaji dan menjelaskan bagaimanakah Perlindungan Hukum Korban Tindak Pidana khususnya Tindak Pidana Penusukan dalam Peradilan Pidana.Berdasarkan uraian latar belakang permasalahan di atas maka judul yang diangkat adalah sebagai berikut: TINJAUAN YURIDIS TERHADAP PERLINDUNGAN HUKUM KORBAN TINDAK PIDANA PENUSUKAN DALAM PERADILAN PIDANA.

\section{B. METODE PENELITIAN}

Penelitian tentang Tindak Pidana Penusukan ini menggunakan metode pendekatan yang berupa pendekatan konseptual (Conceptual Approach) dan Pendekatan Perundang-undangan. Pendekatan konseptual yaitu dilakukan dengan menjabarkan konsep dari Tindak Pidana Penusukan sendiri berupa pengertian, doktrin, dan asas hukum. Pendekatan Undang-Undang yaitu dengan menelaah semua undang-undang dan regulasi yang berkaitan dengan Hukum Pidana. Jenis Data yang digunakan di dalam penelitian hukum adalah data sekunder yang diperoleh dari bahan hukum primer dan bahan hukum sekunder. Teknik yang digunakan untuk memperoleh sumber hukum primer dalam penelitian ini dilakukan dengan cara mengumpulkan, mencari, menginventarisasi, mengkaji dan melakukan penelusuran studi kepustakaan yang berhubungan dengan peraturan perundang-undangan yang mengatur tentang legalitas. Metode analisis data yang digunakan dalam penelitian ini adalah analisis kualitatif.

\section{HASIL DAN PEMBAHASAN}

Indonesia merupakan negara hukum, sehingga masyarakat harus taat dengan peraturan dan norma-norma yang berlaku. Hukum merupakan aturan untuk mengatur tingkah laku manusia dalam kehidupan agar tertib (Manarisip, 2012) Pembangunan nasional Indonesia bertujuan mewujudkan manusia Indonesia yang adil, makmur, 
Jurnal Pembangunan Hukum Indonesia

Volume 2, Nomor 1, Tahun 2020
Program Studi Magister Ilmu Hukum Fakultas Hukum Universitas Diponegoro sejahtera dan damai berdasarkan Pancasila dan Undang-Undang Dasar 1945.

Pancasila adalah sumber dari segala sumber hukum, Pancasila sebagai dasar untuK dan ideologi dan waktu yang sama secara filosofis bangsa Indonesia, keadilan maka sosial bagi seluruh rakyat Indonesia digunakan untuk membangun kembali lembaga-lembaga keadilan dalam sistem peradilan pidana Indonesia, khususnya di sub-sistem Polisi dengan implementasi referensi Pasal 16 (1) huruf ayat I dan 18 ayat (1) Undang-Undang - Undang Nomor 2 tahun 2002 polisi Indonesia untuk penghentian kasus pidana Jangan selalu menggunakan sistem peradilan yaitu sistem kompensasi lebih suka hukuman pidana, tetapi juga mereka berlaku keadilan restoratif sebagai aspek hasil dan hasil pemulihan asset kejahatan (Sudarsono, 2015).

Secara yuridis tindak pidana adalah segala tingkah laku manusia yang bertentangan dengan hukum, dapat dipidana, yang diatur dalam hukum pidana. Tindak pidana penusukan dapat dikenakan salah satu dari pasal-pasal dalam KUHP tentang menghilangkan nyawa seseorang, yang dapat dibagi menjadi dua kelompok yaitu yang disengaja dan tidak disengaja. Seperti Pasal 338 KUHP dengan ancaman pidana lima belas tahun, bila pelaku melakukan tindak pidana pembunuhan dengan cara disengaja, dimana perbuatan pelaku menyebabkan hilangnya nyawa seseorang, yang dapat dibagi menjadi dua kelompok yaitu yang disengaja dan tidak disengaja. Seperti Pasal 338 KUHP dengan ancaman pidana lima belas tahun, bila pelaku melakukan tindak pidana pembunuhan dengan cara disengaja, dimana perbuatan pelaku menyebabkan hilangnya nyawa seseorang dilakukan dengan segera yaitu waktu antara niat dan perbuatan sehingga memberikan kesempatan untuk berpikir tentang cara pelaksanaan penusukan, maka berlaku Pasal 340 KUHP dengan ancaman hukuman penjara seumur hidup atau selama-lamanya dua puluh tahun penjara karena tindak pidana penusukan yang direncanakan lebih dahulu. Direncanakan lebih dahulu (voorbedachte rade) menunjukan suatu ruang waktu yang tidak demikian sempit dan tidak pula demikian lama. Hukum Pidana (KUHP) peninggalan pemerintah Hindia-Belanda yang tentunya telah tertinggal oleh kemajuan yang terjadi dalam kehidupan masyarakat (Yosuki, \& Tawang, 2018).

\section{Unsur-Unsur Tindak Pidana Penusukan dalam Peradilan Pidana}

Simons mengatakan bahwa strafbaar feit ialah kelakuan yang diancam pidana, yang bersifat melawan hukum yang berhubungan dengan kesalahan dan dilakukan oleh orang yang mampu bertanggung jawab. Van Hamel menyatakan istilah strafbaar feit itu sebagai kelakuan manusia yang dirumuskan dalam undang-undang, melawan hukum yang patut dipidana dan dilakukan dengan kesalahan (Krismen, 2013)

Tindak pidana pembunuhan diatur dalam KUHPidana termasuk dalam kejahatan terhadap jiwa orang, yang diatur dalam Bab XIX yang terdiri dari 13 pasal, yakni Pasal 338 sampai dengan Pasal 350. 
Jurnal Pembangunan Hukum Indonesia

Volume 2, Nomor 1, Tahun 2020
Program Studi Magister Ilmu Hukum Fakultas Hukum Universitas Diponegoro
Secara terminologis pembunuhan adalah perbuatan menghilangkan nyawa, atau mematikan. Sedangkan menurut KUHPidana istilah pembunuhan adalah suatu kesengajaan menghilangkan nyawa orang lain.

Menurut Kitab Undang-Undang Hukum Pidana (KUHP) dibedakan antara lain kejahatan yang dimuat dalam Buku II dan Pelanggaran yang dimuat dalam Buku III. Pembagian tindak pidana menjadi "kejahatan" dan "pelanggaran" itu bukan hanya merupakan dasar bagi pembagian KUHP kita menjadi Buku ke II dan Buku ke III melainkan juga merupakan dasar bagi seluruh sistem hukum pidana di dalam perundang-undangan secara keseluruhan.

Menurut cara merumuskannya, dibedakan dalam tindak pidana formil (formeel Delicten) dan tindak pidana materil (Materiil Delicten). Tindak pidana formil adalah tindak pidana yang dirumuskan bahwa larangan yang dirumuskan itu adalah melakukan perbuatan tertentu. Misalnya Pasal 362 KUHP yaitu tentang pencurian. Tindak Pidana materil inti larangannya adalah pada menimbulkan akibat yang dilarang, karena itu siapa yang menimbulkan akibat yang dilarang itulah yang dipertanggungjawabkan dan dipidana.

Menurut bentuk kesalahan, tindak pidana dibedakan menjadi tindak pidana sengaja (dolus delicten) dan tindak pidana tidak sengaja (culpose delicten). Contoh tindak pidana kesengajaan (dolus) yang diatur di dalam KUHP antara lain sebagai berikut: Pasal 338 KUHP (pembunuhan) yaitu dengan sengaja menyebabkan hilangnya nyawa orang lain, Pasal 354 KUHP yang dengan sengaja melukai orang lain. Pada delik kelalaian (culpa) orang juga dapat dipidana jika ada kesalahan, misalnya Pasal 359 KUHP yang menyebabkan matinya seseorang, contoh lainnya seperti yang diatur dalam Pasal 188 dan Pasal 360 KUHP.

Menurut macam perbuatannya, tindak pidana aktif (positif), perbuatan aktif juga disebut perbuatan materil adalah perbuatan untuk mewujudkannya diisyaratkan dengan adanya gerakan tubuh orang yang berbuat, misalnya Pencurian (Pasal 362 KUHP) dan Penipuan (Pasal 378 KUHP). Tindak Pidana pasif dibedakan menjadi tindak pidana murni dan tidak murni. Tindak pidana murni, yaitu tindak pidana yang dirumuskan secara formil atau tindak pidana yang pada dasarnya unsur perbuatannya berupa perbuatan pasif, misalnya diatur dalam Pasal 224,304 dan 552 KUHP.Tindak Pidana tidak murni adalah tindak pidana yang pada dasarnya berupa tindak pidana positif, tetapi dapat dilakukan secara tidak aktif atau tindak pidana yang mengandung unsur terlarang tetapi dilakukan dengan tidak berbuat, misalnya diatur dalam Pasal 338 KUHP, ibu tidak menyusui bayinya sehingga anak tersebut meninggal.

Dengan kata lain berdasarkan pada pengertian yang dikemukakan oleh Lamintang bahwa delik pembunuhan termasuk dalam delik materiil (materieel delict), yang merupakan suatu delik yang dirumuskan secara materiil, yakni delik yang baru dapat dianggap telah selesai dilakukan oleh pelakunya apabila timbul akibat yang dilarang (akibat konstitutif atau constitutief-gevolg) yang tidak 
Jurnal Pembangunan Hukum Indonesia

Volume 2, Nomor 1, Tahun 2020
Program Studi Magister IImu Hukum Fakultas Hukum Universitas Diponegoro dikehendaki oleh Undang-Undang. Menurut Adami Chazawi perbuatan menghilangkan nyawa orang lain terdapat 3 syarat yang harus dipenuhi, yaitu adanya wujud perbuatan, adanya suatu kematian, dan adanya hubungan sebab akibat (causal verband) antara perbuatan dan akibat yang ditimbulkan (Batas, 2016). Ketiga syarat tersebut merupakan satu kesatuan yang bulat, meskipun dapat dibedakan akan tetapi apabila salah satu syarat di atas tidak terpenuhi maka delik pembunuhan dianggap tidak terjadi. Maka dapat disimpulkan bahwa delik pembunuhan dapat terjadi apabila adanya wujud perbuatan serta adanya kematian (orang lain) dan keduanya ada hubungan sebab akibat antara perbuatan dan akibat yang ditimbulkan yakni kematian. Bahwa akibat dari kematian haruslah disebabkan dari perbuatan itu apabila tidak ada causal verband antara keduanya yakni suatu perbuatan dengan akibat yang ditimbulkan yakni matinya orang lain maka delik pembunuhan dianggap tidak terjadi.

Setiap tindak pidana yang terdapat di dalam KUHPidana dapat dijabarkan kedalam unsur-unsur. Unsur sebagai syarat untuk dapat dipidananya suatu perbuatan dari pelaku dan yang muncul dari bagian umum kitab undang-undang dan asas hukum umum. Untuk menjabarkan suatu rumusan delik ke dalam unsur-unsurnya, maka yang harus diperhatikan terlebih dahulu adalah suatu tindakan manusia, dimana tindakan seseorang tersebut telah melakukan sesuatu tindakan yang dilarang oleh undang-undang. Unsur-unsur setiap tindak pidana dibagi menjadi dua macam unsur, yaitu Unsur Subyektif dan Unsur Obyektif.

Dalam KUHPidana tidak ada ketentuan tentang arti kemampuan bertanggungjawab. Yang berhubungan dengan kemampuan bertanggung jawab adalah Pasal 44 KUHPidana (Punuh, 2015). Sedangkan yang dirumuskan dalam Pasal 44 KUHPidana yang hanya mengenai ketidakmampuan bertanggung jawab karena jiwa yang cacat dalam tubuhnya atau terganggu karena penyakit, dan tidak mampu bertanggungjawab atas perbuatannya karena jiwa yang masih muda. Jadi, jika pelaku tidak mampu bertanggungjawab, pelaku akan dilepaskan dari seluruh tuntutan hukum.

Alasan penghapus pidana dapat dibedakan menjadi dua bagian antara lain, alasan pembenar dan alasan pemaaf. Alasan pembenar berkaitan dengan perbuatan dan alasan pemaaf berkaitan dengan sikap batin seseorang. Salah satu yang termasuk dalam alasan pembenar adalah daya paksa dan pembelaan terpaksa. Dalam Pasal 48 KUHP, dinyatakan bahwa siapa pun yang melakukan perbuatan tindak pidana karena pengaruh daya paksa, tidak dipidana. Daya paksa merupakan perbuatan yang dilakukan orang, dimana fungsi batinnya tidak dapat bekerja secara normal karena adanya tekanan-tekanan dari luar, orang itu dapatdimaafkan kesalahannya. Pembelaan terpaksa, terdiri dari dua kata yaitu pembelaan dan terpaksa. Pembelaan yang dimaksud memilki arti bahwa harus ada hal-hal yang memaksa terlebih dahulu sebelum terdakwa melakukan perbuatannya. 
Jurnal Pembangunan Hukum Indonesia

Volume 2, Nomor 1, Tahun 2020
Program Studi Magister Ilmu Hukum Fakultas Hukum Universitas Diponegoro
Sedangkan, terpaksa diartikan tidak ada jalan lain bagi yang terkena untuk pada saat-saat itu melakukan serangan.

\section{Perlindungan Hukum Korban Tindak Pidana Penusukan dalam Peradilan Pidana}

Perlindungan adalah suatu perbuatan untuk melindungi, memberikan pertolongan. Sedangkan hukum menurut J.C.T. Simorangkir dan Woerjono Sastropranoto adalah peraturan-peraturan yang bersifat memaksa yang menentukan tingka laku =]manusia dalam lingkungan masyarakat yang dibuat oleh badan-badan resmi yang berwajib (Simorangkir, \& Sastropratnoto, 2010). Perlindungan hukum sebagai suatu gambaran dari fungsi hukum, yaitu konsep di mana hukum dapat memberikan suatu keadilan, ketertiban, kepastian, kemanfaatan dan kedamaianDalam negara hukum, perlindungan hukum mencerminkan kewajiban dan tanggung jawab yang diberikan dan dijamin oleh negara untuk menghormati, melindungi, menegakkan dan memajukan hak-hak asasi manusia berdasarkan Undang-Undang dan peraturan hukum.

Pasal 1 angka 1 Undang-Undang Nomor 31 Tahun 2014 tentang Lembaga Perlindungan Saksi dan Korban menyatakan pengertian korban adalah seseorang yang mengalami penderitaan pisik, mental, dan atau kerugian ekonomi yang diakibatkan oleh suatu tindak pidana. Pasal 5 ayat (1) UndangUndang Nomor 31 Tahun 2014 (yang selanjutnya ditulis UU PSK) menjelaskan mengenai hak yang diberikan kepada saksi dan korban yang meliputi: memperoleh perlindungan atas keamanan pribadi,
Keluarga, dan harta bendanya, serta bebas dari Ancaman yang berkenaan dengan kesaksian yang akan, sedang, atau telah diberikannya; ikut serta dalam proses memilih dan menentukan bentuk perlindungan dan dukungan keamanan; memberikan keterangan tanpa tekanan; mendapat penerjemah; bebas dari pertanyaan yang menjerat; mendapat informasi mengenai perkembangan kasus; mendapat informasi mengenai putusan pengadilan;mendapat informasi dalam hal terpidana dibebaskan; dirahasiakan identitasnya; mendapat identitas baru; mendapat tempat kediaman sementara; mendapat tempat kediaman baru; memperoleh penggantian biaya transportasi sesuai dengan kebutuhan; mendapat nasihat hukum; memperoleh bantuan biaya hidup sementara sampai batas waktu Perlindungan berakhir; dan/atau mendapat pendampingan.

Wujud implementasi perlindungan korban tindak pidana penusukan sebagai pihak yang dirugikan, korbanpun berhak untuk memperoleh perlindungan atas keamanan pribadi, Keluarga, dan harta bendanya, serta bebas dari Ancaman yang berkenaan dengan kesaksian yang akan, sedang, atau telah diberikannya. Maka sudah sewajarnya apabila nanti korban penusukan mendapatkan perlindungan sesuai yang di maksud pasal 5 ayat (1) huruf a Undang-undang Perlindungan Saksi dan Korban (yang selanjutnya disebut LPSK).

Berdasarkan Pasal 6 Undang-Undang No.31 Tahun 2014 atau UU PSK menyatakan bahwa korban hak asasi manusia yang berat, korban tindak 
Jurnal Pembangunan Hukum Indonesia

Volume 2, Nomor 1, Tahun 2020
Program Studi Magister Ilmu Hukum Fakultas Hukum Universitas Diponegoro pidana terorisme, tindak pidana perdagangan orang, korban penyiksaan korban tindak pidana kekerasan seksual dan korban penganiayaan berat selain yang dimaksud Pasal 5 juga berhak mendapatkan bantuan berupa medis dan bantuan rehabilitasi serta psikologis, namun dalam bantuan tersebut diberikan berdasarkan keputusan Lembaga Pellindungan Saksi dan Korban. Penulis berharap diadakannya Pembaharuan terhadap peraturan tersebut agar, ketika ada korban yang dimaksud dalam Pasal 6 ayat (1) UU PSK, Lembaga Perlindungn Saksi dan Korbann sesuai namanya lebih memaksimalkan dalam memberikan perlindungan terhadap para korban, sebab korban yang dimaksud dalam pasal 6 ayat (1) merupakan korban tindak pidana yang berat yang semestinya apabila LPSK sebagai lembaga yang bertanggung jawab terhadap saksi dan korban mengetahui adanya korban yang dimaksud Pasal 6 ayat (1), tanpa menunggu Laporan dari korban.

Dalam Pasal 7A (1) Undang-undang No 31 Tahun 2014 menyatakan Korban kejahatan berhak mendapat restitusi seperti; kompensasi atas hilangnya penghasiilan mereka; mengganti kerugian yang disebabkan oleh penderitaan secara langsung yang merupakan hasil dari kejahatan; dan atau biaya pengantiann perawatan medis dan atau psikologis;

Restitusi tersebut dapat diberikan kepada semua korban termasuk korban penganiayaan dan pemukulan dimana hal ini diatur berdasarkan Keputusan Lembaga Perllindungan Saksi dan Korban.
Jika korban meninggal dunia diatur dalam Pasal 7A Ayat (6) Undang-undang Nomor 31 tahun 2014 tentang Perlindungan Saksi dan Korban menyatakan bahwa LPSK memberikan teknan kepada pelaku untuk memberikan ganti rugi kepada ahli waris korban, jika mereka yang bertanggungjawab tidak mampu maka sebagai gantinya LPSK selaku perwakilan dari Negara secara otomatis harus memberikan secara langsung tanpa menunggu pelaku ditetapkan tersangka oleh Penyidik.

Dalam proses penegakan hukum pidana paling sedikit ada dua pihak yang terkait di dalamnya, yaitu pihak pelaku tindak pidana (offenders) dan pihak korban kejahatan (victims). Oleh karena itu, maka kedua pihak tersebut harus mendapat perhatian yang seimbang. Dengan demikian, dalam proses penyelesaian perkara pidana tidak ada pihak yang merasa dirugikan baik dipandang dari sudut penegakan hukum pidana maupun dalam usaha penanggulangan kejahatan yang terjadi dalam masyarakat.

Terdapat beberapa faktor yang menyebabkan tidak terungkapnya jumlah kriminalitas seperti korban yang memang tidak tahu bahwa dirinya menjadi korban, misalnya kehilangan harta milik yang sama sekali tidak dirasakan, karena harta milik tersebut banyak sekali jumlahnya; korban tidak mengetahui bahwa secara yuridis ia dapat menuntut kerugian yang ditimbulkan oleh kecurangan pihak lain, misalnya ada kecurangan dalam jual beli barang konsumsi di toko yang tidak sesuai dengan keadaan 
Jurnal Pembangunan Hukum Indonesia

Volume 2, Nomor 1, Tahun 2020
Program Studi Magister Ilmu Hukum Fakultas Hukum Universitas Diponegoro yang sebenarnya. Dalam hal ini korban tidak tahu atau tidak tahu harus berbuat apa; korban telah bersusah payah berhubungan dengan aparat penegak hukum, karena dirasakan kerugiannya tidak terlalu besar dan dapat diabaikan saja, atau merasa bahwa tidak ada gunanya melaporkan; korban justru khawatir akan menderita keadaan yang lebih memalukan jika apa yang dialaminya dilaporkan pada penegak hukum, misalnya dalam hal kejahatan perkosaan dan kejahatan seksual lainnya sedangkan korban takut akan terjadinya pembalasan dari pelaku jika korban melaporkan kejadian yang menimpa dirinya dan pihaknya merasa tidak ada kepastian untuk mendapatkan perlindungan.

Perlindungan korban sudah diatur dalam Undang-undang dasar Republik Indonesia Tahun 1945 mengatur hak asasi manusia pada Pasal 28A sampai 28J, yang menyatakan mengenai hak setiap orang untuk mendapat atas pengakuan, jaminan, perlindungan, dan kepastian hukum yang adil, serta perlakuan yang sama di hadapan hukum. Perlindungan terhadap korban kejahatan seperti korban tindak pidana penusukan jika diteliti perlindungan korban sudah diatur dalam Undangundang dasar Republik Indonesia Tahun 1945 mengatur hak asasi manusia pada Pasal 28A sampai 28J, yang menyatakan mengenai hak setiap orang untuk mendapat atas pengakuan, jaminan, perlindungan, dan kepastian hukum yang adil, serta perlakuan yang sama di hadapan hukum.Pada saat mengamati Perlindungan hokum terhadap korban kejahatan penusukan dapat berupa perlindungan abstrak atau perlindungan tidak langsung, karena jika korban tidak membuat permintaaan untuk meminta perlindungan kepada LPSK, tidak akan mendapatkan perlindungan, dan bahkan permohonan tersebut harus di pelajari dan diperiksa secara rinci saat permohonan yang diajukan dalam keadaan mendesak, tekanan dari luar maupun dalam dan kerugian yang besar, maka baru LPSK memberikan perlindungan kepada korban, namun Korban sebagai pihak yang dirugikan dalam kejahatan tetapi tidak menerima perhatian secara menyeluruh. Perlindungan korban kejahatan penting keberadaan penderitaan korban ini penting karena keberadaan peneritaan korban kejahata, namun berakhir dengan putusan pengadilan dan berakhirnya hukuman. Untuk memperoleh perlindungan, Permohonan yang dibuat oleh korban atau keluarga dan atau kuasa hukum (advokat)n korban, mendapatkan restitusi serta kompensasi jika korban tidak menjadi aktif mengajukan permintaan memohon perlindungan korban tidak dapat menerima haknnya yang berupa restitusi dan kompensasi.

Selain itu kerugian yang dialami para korban juga dapat berupa mental dan psikis yang saat ini belum diatur dalam UU LPSK, maka dalam hal ini Penulis berpendapat dibutuhkannya kompensasi kepada korban yang dalam bentuk biaya hidup karena biaya hidup yang diberikan ketika peroses perkara persidangan berlangsung, hal ini akan memperbaiki mental dan psikis korban, dimana negara maupun pelaku telah memperhatikan korban, serta jika dibutuhkan korban memperoleh ajaran 
Jurnal Pembangunan Hukum Indonesia

Volume 2, Nomor 1, Tahun 2020
Program Studi Magister Ilmu Hukum Fakultas Hukum Universitas Diponegoro yang bersifat keagamaan seperti memberikan pembelajaran yang merupakan motifasi bagi para korban dan keluargannya. Oleh karena itu korban juga merasa tenang dalam hatinya, maka dari itu didalam lembaga perlindungan saksi dan korban dibutuhkannya seseorang yang mampu memberikan kompensasi tersebut kepada korban, karena sifart dari motivasi belajar hal itu akan mendorong korban untuk lebih tenang kejiwaanya setelah kejadian yang menimpa korban.

Penulis berharap Lembaga Perlindungan Saksi dan Korban diharapkan untuk aktif dalam menangani perlindungan korban, tanpa menunggu permohonan yang diajukan oleh korban atau keluarga atau hukum nasihatnya korban, jika Lembaga tidak mengetahui adanya tindak pidana itu dilakukan, maka informasi permintaan dari polisi atau bekerja sama dalam kaitannya dengan kejahatan yang terjadi, polisi untuk lembaga perlindungan saksi korban dan kejahatan terkait, sesuai dengan Undang-Undang Nomor 2 tahun 2002 tentang Indonesia polisi Pasal nasional 4 dari tujuan kepolisian nasional Indonesia untuk melakukan keamanan internal termasuk menjaga ketertiban umum dan keamanan, ketertiban dan aturan hukum, pelaksanaan perlindungan, tempat tinggal dan pelayanan terhadap perdamaian komunitas dan masyarakat terbinanya untuk membela hak asasi manusia.

Pemidanaan yang merupakan tindakan seorang penjahat. Pidana dijatuhkan agar pelaku tidak melakukan tindak pidana dan orang lain takut melakukan kejahatan serupa. Pemidanaan bukan dimaksudkan sebagai upaya balas dendam melainkan sebagai upaya pembinaan agi seorang pelaku kejahatan sekaligus upaya preventif terhadap terjadinya kejahatan yang serupa.

Sehubungan dengan istilah sistem, dalam ilmu hukum pidana sering dibicarakan adanya sistem pidana dan pemidanaan Dalam Pasal 183 KUHAP menunjukan bahwa hukum acara pidana positif Indonesia menganut sistem pembuktian negatif (negative bewijstheorie) (negative bewijstheorie) atau yang disebut juga dengan pembuktian UndangUndang secara negatif (negative wettelijke) (negative wettelijke). Alasannya karena dalam penerapan KUHPidana lebih menggunakan cara dan alat-alat bukti yang berada dalam Undang-Undang serta dengan keyakinan hakim.

Peradilan pidana seharusnya berdasarkan kualitas dan kuantitas dengan penderitaan dan kerugian yang diderita korban. Dalam Peraturan Perundang-undangan yang berlaku belum mengatur secara rinci mengenai ganti kerugian yang diberikan korban tindak pidana penusukan, Sebagaimana diuraikan beberapa bentuk perlindungan terhadap korban agar perlindungan kepada korban terwujud dan bisa dirasakan oleh koban yakni putusan hakim yang memuat mengenai ganti rugi, Restitusi dan Kompensasi.

Dalam KUHAP istilah ganti rugi diatur dalam Pasal 99 ayat (1) dan (2) dengan penekanan pada pengantian biaya yang telah dikeluarkan oleh pihak yang dirugikan atau korban. ini berarti bahwa 
Jurnal Pembangunan Hukum Indonesia

Volume 2, Nomor 1, Tahun 2020
Program Studi Magister Ilmu Hukum Fakultas Hukum Universitas Diponegoro kehilangan yang dimaksud adalah kerusakan material. Sementara itu, kerusakan material tidak termasuk dalam percakapan hukum acara pidana. penggantian kerugian korban berupa memenuhi kerusakan material dan semua biaya yang telah di keluarkan, dan emossional dari korban. Sedangkan dari segi kepentingan pelaku, berubah kewajiban mereka dilihat sebagai bentuk dari hukuman yang dikenakan dan dianggap sebagai sesuatu yang konkret, sedangkan restitusi lebih berfokus pada tanggung jawab penulis konsekuensi yang disebabkan oleh kejahatan sehingga tujuan utama adalah untuk mengatgasi semua kerugian yang diderita korban, selain kompensasi, restitusi, kompensasai. Komensasi adalah bentuk dari ganti rugi yang dapat dilihat dari aspek kemanusiaan dan hak asasi manusia.

Dari tiga komponen diatas merupakan perlindungan yang perlu diterapkan kepada korban, sebab selama ini putusan hakim tidak memuatkan ganti kerugian, restitusi dan kompensasi, sehingga dengan adanya tiga komponen tersebut perlindungan korban dapat terwujud. Perlindungan hukum dalam KUHAP dan Undang-Undang Perlindungan Saksi Dan Korban belum dapat dikatakan efektif untuk kepentingan dan penderitaan yang dialami korban kejahatan, oleh karena itu KUHAP dan UndangUndang Perlindungan Saksi Dan Korban mengatur tentang ganti rugi hanya terpaku pada kerugian yang bersifat materiil itupun sulit diterapkan kepada korban baik melalui lembaga perlindungan korban ataupun melalui putusan Hakim. Sebab didalam undang- undang LPSK terpaku dengan adanya peraturan tentang perlindungan diberikan terhadap korban jika korban membuat permohonan yang diajukan kepada LPSK, apabila korban tidak membuat permohonan yang diajukan kepada LPSK. Maka ia tidak mendapatkan perlindungan yang berupa restitusi maupun kompensasi.

Dari 3 komponen diatas ialah proteksi yang butuh diterapkan kepada korban, karena sepanjang ini vonis hakim tidak memuatkan ubah kerugian, restitusi serta kompensasi, sehingga dengan terdapatnya 3 komponen tersebut proteksi korban bisa terwujud. Proteksi hukum dalam KUHAP serta Undang- Undang Proteksi Saksi Serta Korban belum bisa dikatakan efisien buat kepentingan serta penderitaan yang dirasakan korban kejahatan, oleh sebab itu KUHAP serta Undang- Undang Proteksi Saksi Serta Korban mengendalikan tentang ubah rugi cuma terpaku pada kerugian yang bertabiat materiil itupun susah diterapkan kepada korban baik lewat lembaga proteksi korban maupun lewat vonis Hakim. Karena didalam undang- undang LPSK terpaku dengan terdapatnya peraturan tentang proteksi diberikan terhadap korban bila korban membuat permohonan yang diajukan kepada LPSK, apabila korban tidak membuat permohonan yang diajukan kepada LPSK. Hingga dia tidak memperoleh proteksi yang berbentuk restitusi ataupun kompensasi.

Proteksi hukum wajib cocok dengan pandangan hidup pancasila. Indonesia ialah negeri hukum sepatutnya membagikan proteksi hukum terhadap masyarakat masyarakatnya yang cocok 
Jurnal Pembangunan Hukum Indonesia

Volume 2, Nomor 1, Tahun 2020
Program Studi Magister Ilmu Hukum Fakultas Hukum Universitas Diponegoro dengan pancasila spesialnya terhadap korban kejahatan. Sebab korban merupakan seorang yang sangat dirugikan dalam kejahatan tersebut, Oleh sebab itu proteksi hukum bersumber pada pancasila berarti pengakuan serta proteksi hendak harkat serta martabat korban atas dasar nilai keTuhanan, kemanusiaan, persatuan ataupun permusyawaratan dan keadilan sosial.

Dalam sistem hukum pidana para penegak hukum dituntut mengedapankan kejujuran serta ketulusan dalam melaksanakan sistem hukum, mereka wajib memiliki empati serta kepedulian terhadap penderitaan korban tindak pidana. Kepentingan terhadap korban( kesejahteraan serta kebahagiaan) wajib jadi titik orientasi serta tujuan akhir dalam penyelenggaraan sistem hukum.

Dalam contoh kasus Penusukan yang terjadi kepada Wiranto, Penusukan termasuk kedalam pembunuhan berencana sebagaimana diatur dalam Pasal 340 KUHPidana yang menyatakan bahwa barang siapa sengaja dan dengan rencana lebih dahulu merampas nyawa orang lain, diancam karena pembunuhan dengan rencana (moord) (moord), dengan pidana mati atau pidana penjara seumur hidup atau selama waktu tertentu, paling lama dua puluh tahun .

Selain melanggar KUHPidana pelaku telah melanggar Pasal 6 Undang-Undang Nomor 5 tahun 2018 tentang Pemberantasan Tindak Pidana Terorisme yang menyatakan bahwa setiap orang yang dengan sengaja menggunakan Kekerasan yang mengakibatkan kerusakan atau kehancuran terhadap
Objek Vital yang Strategis, lingkungan hidup atau Fasilitas Publik atau fasilitas internasional dapat dikenakan sanksi.

Undang-undang yang mengatur tentang pemberian kompensasi restitusi dan bantuan hukum kepada korban kejahatan diatur dalam Peraturan pemerintah No.44 Tahun 2008 Tentang Pemberian Kompensasi, Restitusi dan bantuan hukum kepada saksi dan korban dinyatakan dalam Pasal 2 ayat (1) menyatakan bahwa korban pelanggaran hak asasi manusia yang berat berhak memperoleh Kompensasi. Korban Penusukan berhak mendapatkan kompensasi sebagaimana disebutkan dalam Peraturan pemerintah No.44 Tahun 2008.

Proteksi korban pada KUHAP penegakan hukum kelemahan mendasar merupakan tidak terpenuhinya hak korban kejahatan dalam proses penangan masalah pidana ataupun akibat yang wajib ditanggung oleh korban kejahatan sebab proteksi hukum terhadap korban kejahatan tidak memperoleh peraturan yang secara spesial mengendalikan menimpa tindak pidana penusukan. Perihal ini bisa dilihat dalam KUHAP sedikit Pasal- Pasal yang mangulas tentang korban, pembahasannya juga tidak fokus terhadap eksistensi korban tindak pidana melainkan cuma bagaikan masyarakat negeri biasa yang memiliki hak yang sama dengan masyarakat negeri yang yang lain. Sebutan yang digunakan dalam kedudukan dan peran korban. Semacam dalam Pasal 160 ayat 1b kitab undang- undang hukum kegiatan pidana disebutkan kalau“ yang awal didengar keterangannya merupakan korban yang jadi 
Jurnal Pembangunan Hukum Indonesia

Volume 2, Nomor 1, Tahun 2020
Program Studi Magister Ilmu Hukum Fakultas Hukum Universitas Diponegoro saksi". Dengan demikian posisi korban tindak pidana dalam KUHAP hannyalah bagaikan saksi dari sesuatu masalah pidana yang sekedar buat meyakinkan kesalahan terdakwa ataupun tersangka. Proteksi hukum wajib cocok dengan pandangan hidup pancasila. Indonesia ialah negeri hukum sepatutnya membagikan proteksi hukum terhadap masyarakat masyarakatnya yang cocok dengan pancasila spesialnya terhadap korban kejahatan. Sebab korban merupakan seorang yang sangat dirugikan dalam kejahatan tersebut, Oleh sebab itu proteksi hukum bersumber pada pancasila berarti pengakuan serta proteksi hendak harkat serta martabat korban atas dasar nilai keTuhanan, Kemanusiaan, persatuan ataupun permusyawaratan dan keadilan sosial.

Dalam sistem hukum pidana para penegak hukum dituntut mengedapankan kejujuran serta ketulusan dalam melaksanakan sistem hukum, mereka wajib memiliki empati serta kepedulian terhadap penderitaan korban tindak pidana. Kepentingan terhadap korban( kesejahteraan serta kebahagiaan) wajib jadi titik orientasi serta tujuan akhir dalam penyelenggaraan sistem hukum.

Kedudukan korban dan perlindungannya tidak diatur khusus sebagaimana dikemukakan pada babbab terdahulu, korban dalam KUHAP hanya diatur dalam beberapa Pasal saja. Pasal 98 ayat (1) KUHAP menyatakan bahwa Jika suatu perbuatan yang menjadi dasar dakwaan di dalam suatu pemeriksaan perkara pidana oleh pengadilan negeri menimbulkan kerugian bagi orang lain, maka hakim ketua sidang atas permintaan orang itu dapat menetapkan untuk menggabungkan perkara gugatan ganti kerugian kepada perkara pidana itu (Wibowo, 2016).

Pasal 99 ayat (1) KUHAP menyebutkan bahwa Apabila pihak yang dirugikan minta penggabungan perkara gugatannya pada perkara pidana sebagaimana dimaksud Pasal 98, maka pengadilan negeri menimbang tentang kewenangannya untuk mengadili gugatannya tersebut, tentang kebenaran dasar gugatan dan tentang hukum penggantian biaya yang dirugikan tersebut. Ayat (2) kecuali dalam hal pengadilan negeri menyatakan tidak berwenang mengadili gugatan sebagaimana dimaksud ayat (1) atau gugatan tidak dapat diterima, putusan hakim hanya memuat tentang penetapan hukuman pengantian biaya yang telah dikeluarkan oleh pihak yang dirugikan. Ayat (3) berbunyi, putusan mengenai ganti kerugian dengan sendirinya mendapat kekuatan tetap apabila putusan pidananya juga mendapat kekuatan hukum tetap.

Pasal 100 ayat (1) KUHAP menyatakan bahwa apabila terjadi penggabungan perkara perdata dan perkara pidana maka pengabungan itu dengan sendirinya berlangsung dalam pemeriksaan tinggat banding. Ayat (2) menyatakan apabila terhadap suatu perkara pidana tidak diajukan permintaan banding, maka permintaan banding mengenai putusan ganti rugi tidak diperkenankan.

Pasal 98- 100 KUHAP ialah Pasal- Pasal yang berkaitan dengan hak korban dalam menuntut ubah kerugian. Mekanisme yang ditempuh merupakan 
Jurnal Pembangunan Hukum Indonesia

Volume 2, Nomor 1, Tahun 2020
Program Studi Magister Ilmu Hukum Fakultas Hukum Universitas Diponegoro mencampurkan masalah gugatan ubah kerugian pada masalah pidana. Penggabungan masalah ubah kerugian ialah syarat yang terdapat dalam KUHAP( Yulia, 2013). Tetapi syarat Pasal- Pasal tersebut susah diterapkan apalagi tidak terdapat korban yang menuntut syarat ubah kerugian dalam KUHAP, karena dalam prosedurnya di anggap sangat rumit sekali. Sebab buat mengajukan gugatan ubah rugi dikira dalam ranah masalah perdata yang mengunakan biayanya diucap bayaran masalah perdata supaya masalah tersebut bisa di jalankan cocok syarat majelis hukum. Supaya masalah pidana tentang ganti- rugi ataupun konpensasi tidak susah buat diterapkan terpaut dengan proteksi korban kejahatan, telah sepantasnya penuntut universal kedepanya sanggup mencampurkan antara tuntutan serta gugatan terpaut dengan ubah rugi yang wajib diberikan korban kejahatan. Menimpa gugatan pidana yang diajukan Jaksa penuntut universal dalam positanya termuat kerugian- kerugian ataupun penderitaan yang dirasakan oleh korban tindak pidana kejahatan berikutnya petitumnya muat perhohonan ganti- rugi, kompensasi yang dimohonkan kepada majelis hakim supaya membagikan vonis ataupun mengabulkan gugatan dan tuntunya jaksa penuntut universal. Perihal tersebut berarti sekali menimpa proteksi terhadap korban kejahatan. Perihal demikian bisa dicoba apabila korban belum memperoleh ubah rugi dari pelakon. Karena hukum buat manusia spesialnya orang yang dirugikan( korban) tindak pidana. Apabila syarat gugatan digabungkan dengan tuntutan, hingga disana keberadaan korban kejahatan diperjuangkan oleh negeri yang diwakili jaksa penuntut universal dalam peradilan Proteksi korban ialah salah satu subsistem dari sistem hukum pidana. Makna sistem dalam bermacam teori yang berpandangan itu tidak senantiasa jelas serta tidak pula seragam. Dalam sistem hukum pidana para penegak hukum dituntut mengedapankan kejujuran serta ketulusan dalam melaksanakan sistem hukum, mereka wajib memiliki empati serta kepedulian terhadap penderitaan korban tindak pidana. Kepentingan terhadap korban( kesejahteraan serta kebahagiaan) wajib jadi titik orientasi serta tujuan akhir dalam penyelenggaraan sistem hukum.

Undang-undang Nomor 31 tahun 2014 tentang Perlindungan Saksi dan Korban pada Pasal 28 menyatakan bahwa perlindungan disebutkan dalam ayat (1) huruf a sampai huruf $d$ menyatakan bahwa Perlindungan LPSK terhadap Saksi dan atau Korban diberikan dengan syarat mengenai sifat pentingnya keterangan Saksi dan atau Korban; tingkat Ancaman yang membahayakan; hasil analisis tim medis atau psikolog terhadap Saksi dan atau Korban; dan rekam jejak tindak pidana yang pernah dilakukan.

Oleh karena itu kedudukan dan peran korban akan sangat tergantung pada peradilan pidana yang dianut dan dijalankan negara. Jika suatu perbuatan dirumuskan sebagai perbuatan pidana, maka segala upaya yang perlu dilakukan terhadap perbuatan itu menjadi hak monopoli aparat penegak hukum. Korban cukup memberikan laporan atau pengaduan, tindakan selanjutnya diserahkan kepada aparat 
Jurnal Pembangunan Hukum Indonesia

Volume 2, Nomor 1, Tahun 2020
Program Studi Magister Ilmu Hukum Fakultas Hukum Universitas Diponegoro penegak hukum (polisi). Laporan atau pengaduan berguna bagi kepolisian untuk melakukan tindakan penyelidikan. Dengan demikian dalam tingkat penyelidikan kedudukan dan peran korban sebatas sebagai pelapor dan pembuat aduan. Apabila dalam penyelidikan tersebut kepolisian mendapat kepastian akan tindak pidana yang terjadi, maka langkah selanjutnya adalah melakuakan penyidikan. Peradilan pidana selama ini lebih mengutamakan perlindungan kepentingan pelaku tindak pidana. Padahal peran penegak hukum dalam peradilan pidana sebagai institusi yang berwenang menjatuhkan sanksi pidana, hanya terbatas pada pemberian perlindungan kepada tersangka atau terdakwa dan menganggap bahwa kepentingan dalam memberikan perlindungan kepada korban tindak pidana diwakili oleh jaksa penuntut umum. Lebih baiknya jaksa penuntut umum memiliki peraturan yang baku memuat tentang kerugian atau penderitaan korban kejahatan yang harus di kembalikan oleh pelaku tindak pidana, sebab penuntut umum institusi yang mewakili korban tindak pidana kejahatan.

Pengungkapan suatu kasus kejahatan oleh korban selamanya tidak berjalan mulus, banyak korban yang enggan dan merasa takut untuk melaporkan kejadian yang mereka alami, berbagai ancaman dan teror yang menakutkan atas keselamatan dirinya dan keluarganya menjadi alasan penghambat peranan korban tindak pidana dalam sistem peradilan pidana.Oleh sebab itu peran ganti rugi terhadap korban sangat perlu diterapkan, agar dirinya tidak takut dan dengan sukarela untuk melaporkan perkara yang ia alami kepada penyidik. Apabila ganti-rugi tidak didapatkan dan peran korban tidak dianggap, maka dapat dikatakan nasib korban memang tragis. la sudah mengalami penderitaan, kerugian atau kehilangan sebagai akibat dari tindak pidana sama sekali tidak mendapat hak sedikitpun untuk memilih reaksi macam apa dan bagaimana cara pelaksanaannya yang layak diberikan terhadap pelaku atau paling tidak apa yang harus diperbuat atau dibebankan kepada pelaku untuk meringankan penderitaannya sebagai korban. Bahkan seringkali posisi dan keadaannya dieksploitasi oleh birokrasi peradilan demi untuk memperlancar tugas-tugas normatif yang mereka emban. Kedudukan tidak menguntungkan yang dialami korban dalam sistem peradilan pidana sekarang ini tidak terlepas dari konsekuensi pemisahan yang tajam antara bidang hukum pidana dengan hukum perdata. Perselisihan yang terjadi dalam bidang hukum perdata dianggap urusan privat mereka yang berselisih, sehingga penyelesaiannya di serahkan sepenuhnya oleh para pihak. Dengan hal tersebut untuk memberikan peran kepada korban, ia diberi wewenang untuk meminta ganti rugi yang nantinya diwakili oleh jaksa penuntut umum.

Proteksi tidak terlepas dari proteksi terhadap korban, proteksi sangatlah berarti spesialnya kepada korban. Sebeb korban merupakan pihak yang sangat dirugikan dalam kejahatan pidana, hingga hukum wajib sanggup melindungi terhadap kepentingan dan hak- hak korban. Proteksi hak- hak korban tindak 
Jurnal Pembangunan Hukum Indonesia

Volume 2, Nomor 1, Tahun 2020
Program Studi Magister Ilmu Hukum Fakultas Hukum Universitas Diponegoro pidana kejahatan penusukan belum terdapat pasal tentu yang mengendalikan menimpa hak- hak korban. Dalam KUHAP mengendalikan syarat terpaut dengan proteksi hukum semacam restitusi, kompensasi yang jelas terhadap korban kejahatan, dan didalam Undang- Undang Lembaga Proteksi Saksi serta Korban muat syarat peratuaran pasal yang jelas, tegas menimpa proteksi hukum restitusi, kompensasi terhadap korban tindak pidana semacam lembaga proteksi saksi serta korban membagikan proteksi yang berbentuk restitusi ataupun proteksi kompensasi dan lembaga dorongan hukum semenjak terdapatnya korban. Bila proteksi terhadap korban, dikala pelakon diresmikan bagaikan terdakwa, tersangka, proteksi tersebut belum dapat dialami jikalau mengacu pada undangundang LPSK, karena dalam proses korban buat memperoleh proteksi menunggu vonis majelis hukum yang telah menetapkan tersangka bagaikan terpidana yang telah berkekuatan hukum.

Dalam sistem peradilan pidana diharapkan bisa melaksanakan guna hukum pidana baik hukum kegiatan pidana( hukum resmi) ataupun hukum pidana materiilnya. Dengan berjalannya sistem peradilan pidana sepatutnya ditegakan keadilan, kepastian hukum, hak asasi manusia dalam rangka proteksi hukum semacam restitusi kompensasi terhadap korban. Bagi Sudikno Mertokusumo serta A. Pitlo, menafsirkan undang- undang tidak boleh menyimpang dari sistem perundang - undangan (Tutik, 2012).
Dengan demikian sistem peradilan pidana pasti memiliki bagian- bagian yang bisa diucap pula bagaikan sub- sistem, yang bekerja secara sinergis buat menggapai tujuan penegakan hukum pidana. Sub- sistem dari peradilan pidana tersebut terdiri dari kepolisian, kejaksaan, majelis hukum( kehakiman), serta lembaga koreksi, baik yang bertabiat institusional ataupun non- institusional.

Di Indonesia tindak pidana terjalin ataupun dilaporkan ataupun diadukan aksi kepada penyelidik serta penyidik. Penyelidikan dicoba polisi buat mencari serta menciptakan sesuatu pristiwa yang diprediksi bagaikan tindak pidana guna memastikan bisa tidaknya dicoba penyidikan. Apabila dalam penyelidikan tersebut didapat kepastian kalau kejadian yang terjalin ialah tindak pidana, hingga polisi hendak melaksanakan penyidikan. Perihal tersebut supaya bisa mencari ataupun mengumpulkan fakta guna membuat cerah tentang tindak pidana yang terjalin serta menciptakan tersangkanya. Aksi tingkatan penyelidikan serta penyidikan tersebut ialah rangkaian tidakan yang dicoba oleh kepolisian.

Oleh sebab itu peran serta kedudukan korban hendak sangat bergantung pada peradilan pidana yang dianut serta dijalankan negeri. Bila sesuatu perbuatan diformulasikan bagaikan perbuatan pidana, hingga seluruh upaya yang butuh dicoba terhadap perbuatan itu jadi hak dominasi aparat penegak hukum. Korban lumayan membagikan laporan ataupun pengaduan, aksi berikutnya diserahkan kepada aparat penegak hukum( polisi). 
Jurnal Pembangunan Hukum Indonesia

Volume 2, Nomor 1, Tahun 2020
Program Studi Magister Ilmu Hukum Fakultas Hukum Universitas Diponegoro
Laporan ataupun pengaduan bermanfaat untuk kepolisian buat melaksanakan aksi penyelidikan. Dengan demikian dalam tingkatan penyelidikan peran serta kedudukan korban sebatas bagaikan pelapor serta pembuat aduan. Apabila dalam penyelidikan tersebut kepolisian menemukan kepastian hendak tindak pidana yang terjalin, hingga langkah berikutnya merupakan melakuakan penyidikan. Peradilan pidana sepanjang ini lebih mengutamakan proteksi kepentingan pelakon tindak pidana. Sementara itu kedudukan penegak hukum dalam peradilan pidana bagaikan institusi yang berwenang menjatuhkan sanksi pidana, cuma terbatas pada pemberian proteksi kepada terdakwa ataupun tersangka serta menyangka kalau kepentingan dalam membagikan proteksi kepada korban tindak pidana diwakili oleh jaksa penuntut universal. Lebih baiknya jaksa penuntut universal mempunyai peraturan yang baku muat tentang kerugian ataupun penderitaan korban kejahatan yang wajib di kembalikan oleh pelakon tindak pidana, karena penuntut universal institusi yang mewakili korban tindak pidana kejahatan.

Pengungkapan sesuatu permasalahan kejahatan oleh korban selamanya tidak berjalan lembut, banyak korban yang enggan serta merasa khawatir buat memberi tahu peristiwa yang mereka natural, bermacam ancaman serta teror yang menakutkan atas keselamatan dirinya serta keluarganya jadi alibi penghambat peranan korban tindak pidana dalam sistem peradilan pidana. Oleh karena itu kedudukan ubah rugi terhadap korban sangat butuh diterapkan, supaya dirinya tidak khawatir serta dengan sukarela buat memberi tahu masalah yang dia natural kepada penyidik. Apabila ganti- rugi tidak didapatkan serta kedudukan korban tidak dikira, hingga bisa dikatakan nasib korban memanglah tragis. Dia telah hadapi penderitaan, kerugian ataupun kehabisan bagaikan akibat dari tindak pidana sama sekali tidak menemukan hak sedikitpun buat memilah respon berbagai apa serta gimana metode penerapannya yang layak diberikan terhadap pelakon ataupun sangat tidak apa yang wajib diperbuat ataupun dibebankan kepada pelakon buat meringankan penderitaannya bagaikan korban. Apalagi acapkali posisi serta keadaannya dieksploitasi oleh birokrasi peradilan demi buat memperlancar tugas - tugas normatif yang mereka emban. Peran tidak menguntungkan yang dirasakan korban dalam sistem peradilan pidana saat ini ini tidak terlepas dari konsekuensi pembelahan yang tajam antara bidang hukum pidana dengan hukum perdata. Perselisihan yang terjalin dalam bidang hukum perdata dikira urusan privat mereka yang berselisih, sehingga penyelesaiannya di serahkan seluruhnya oleh para pihak. Dengan perihal tersebut buat membagikan kedudukan kepada korban, dia diberi wewenang buat memohon ubah rugi yang nantinya diwakili oleh jaksa penuntut universal.

\section{SIMPULAN}

Peraturan tindak pidana penusukan belum diatur secara khusus namum KUHPidana yang menyatakan bahwa Penusukan dapat dikategorikan dalam 
Jurnal Pembangunan Hukum Indonesia

Volume 2, Nomor 1, Tahun 2020
Program Studi Magister Ilmu Hukum Fakultas Hukum Universitas Diponegoro pembunuhan berencana sebagaimana diatur dalam Pasal 340 KUHPidana yang menyatakan diancam karena pembunuhan dengan rencana (moord), serta diatur dalam Pasal 6 Undang-Undang Nomor 5 tahun 2018 tentang Pemberantasan Tindak Pidana Terorisme yang menyatakan Ancaman Kekerasan yang menimbulkan rasa takut atau Seharusnya tindak pidana penusukan diatur secara khusus mengenai peraturan perundang-undangannya dan korban tindak pidana penusukan harus mendapatkan perlindungan hukum serta Pelaku tindak pidana diberikan sanksi yang memberikan efek jera kepada pelaku tersebut.

\section{DAFTAR PUSTAKA}

\section{BUKU}

Simorangkir, J.C.T., \& Sastropratnoto, Woerjono. (2010). Hukum Indonesia. Jakarta: Gunung Agung.

Yulia. (2013). Viktimologi Perlindungan Hukum terhadap Korban Kejahatan. Yogyakarta: Graha ilmu.

\section{SKRIPSI}

Wijaya, Feiby V. (2017). Tinjauan Yuridis terhadap Tindak Pidana Kekerasan Terhadap Anak yang dilakukan oleh anak. Universitas Hassanudin

\section{JURNAL}

Wibowo, A. (2016). Sumbangan Pemikiran Hak Asasi Manusia Terhadap Pembaharuan Kitab
Undang-Undang Hukum Acara Pidana (KUHAP). J urnal Media Hukum. Vol 23 (No.2), pp. 128-136.

Sudarsono. C. (2015). Pelaksanaan Mediasi Penal dalam Penyelesaian Tindak Pidana Penganiayaan. Unnes Law Journal, Vol.4, (No.1), pp.20-34.

Chandra. (2017). Correlation between theory of criminal liability and criminal punishment toward corporation in indonesia criminal justice. J urnal Dinamika Hukum, Vol.17, (No. 1), pp.105-111.

Ediwarman. (2012). Paradoks Penegakan Hukum Pidana dalam Perspektif Kriminologi di Indonesia. J urnal Kriminologi Indonesia, Vol.8, (No.1), pp. 38-51.

Hidayat, E. (2016). Perlindungan Hak Asasi Manusia dalam Negara Hukum Indonesia. J urnal Raden Intan Lampung, Vol.8, (No.2), pp. 80-87.

Batas, Ewis M. (2016). Tindak Pidana Pembunuhan Berencana Menurut Pasal 340 KUHPidana. Lex Crimen, Vol. V, (No.2), pp.118-125.

Folman, P. (2018). Penanggulangan Tindak Pidana Terorisme. Binamulia Hukum, Vol. 7, pp.141156

Manarisip, M. (2012 ). Eksistensi Pidana Adat dalam Hukum Nasional. Lex Crimen, Vol.I, (No.4), pp. 24-40.

Maksum, M. (2015). Penerapan Hukum Jaminan Fidusia dalam kontrak Pembiayaan Syari"ah. J urnal Cita Hukum, Vol.3, (No.1), pp.1-10. 
Jurnal Pembangunan Hukum Indonesia

Volume 2, Nomor 1, Tahun 2020
Program Studi Magister Ilmu Hukum Fakultas Hukum Universitas Diponegoro
Rohmanto. (2019). Penegakan Hukum terhadap Tindak Pidana Penipuan Berbasis Transaksi Elektronik. Jurnal Penelitian Hukum, Vol.19, (No.1), pp.31-51.

Wahidin, S.(2000). Perlindungan Hukum terhadap Masyarakat akibat Pemberitaan Pers. Jurnal IImu Hukum, Vol.7, (No.13), pp.130-137.

Punuh, Stedy R. (2015). Kemampuan Bertanggungjawab dalam Pasal 44 KUHPidana. Lex Crimen, Vol. IV, (No.3), pp.83-89.

Sudira, I Ketut. (2014). The Construction of Penal Mediation Model in Handling Family Negclect Cases in the Future. International J ournal of Education and Research, Vol.2, (No.8), pp. 429-438.

Tutik, Titik T. (2012). Hakikat Keilmuan IImu Hukum ditinjau dari Sudut Filsafat IImu dan Teori IImu Hukum. Mimbar Hukum, Vol.24, (No.3), pp.444-458.

Krismen, Y.(2014). Pertanggungjawaban Pidana Korporasi dalam Kejahatan Ekonomi. Jurnal IImu Hukum. Vol.4, (No.1), pp. 133-160.

Yosuki, Aska., \& Tawang, Dian Adriawan Daeng. (2018). Kebijakan Formulasi Terkait Konsepsi rechterlijk pardon (permaafan hakim) dalam pembaharuan hukum pidana di Indonesia. J urnal Hukum Adigama, Vol.1, (No.1), pp.1-25. Amalia, Rizki., Siswanto, Heni., \& WN, Damanhuri. (2017). Analisis Yuridis Penegakan Hukum Pidana Terhadap Tindak Pidana Penipuan
Bisnis Online. POENALE ; Jurnal Bagian Hukum Pidana, Vol.5, (No.3), pp.1-11. 